University of Montana

ScholarWorks at University of Montana

10-2006

\title{
Invasion Through Quantitative Effects: Intense Shade Drives Native Decline and Invasive Success
}

Kurt O. Reinhart

Julie Gurnee

Reyes Tirado

Ragan M. Callaway

University of Montana - Missoula, Ray.Callaway@mso.umt.edu

Follow this and additional works at: https://scholarworks.umt.edu/biosci_pubs

Part of the Biology Commons

Let us know how access to this document benefits you.

\section{Recommended Citation}

Reinhart, Kurt O.; Gurnee, Julie; Tirado, Reyes; and Callaway, Ragan M., "Invasion Through Quantitative Effects: Intense Shade Drives Native Decline and Invasive Success" (2006). Biological Sciences Faculty Publications. 227.

https://scholarworks.umt.edu/biosci_pubs/227

This Article is brought to you for free and open access by the Biological Sciences at ScholarWorks at University of Montana. It has been accepted for inclusion in Biological Sciences Faculty Publications by an authorized administrator of ScholarWorks at University of Montana. For more information, please contact scholarworks@mso.umt.edu. 


\title{
INVASION THROUGH QUANTITATIVE EFFECTS: INTENSE SHADE DRIVES NATIVE DECLINE AND INVASIVE SUCCESS
}

\author{
Kurt O. Reinhart, ${ }^{1,3}$ Julie Gurnee, ${ }^{1}$ Reyes Tirado, ${ }^{2,4}$ and Ragan M. Callaway ${ }^{1}$ \\ ${ }^{1}$ The University of Montana, Division of Biological Sciences, Missoula, Montana 59812 USA \\ ${ }^{2}$ Estación Experimental de Zonas Áridas, CSIC, C/ General Segura 1, 04001 Almería, Spain
}

\begin{abstract}
The effects of invasive nonnative species on community composition are well documented. However, few studies have determined the mechanisms by which invaders drive these changes. The literature indicates that many nonnative plant species alter light availability differently than natives in a given community, suggesting that shading may be such a mechanism. We compared light quantity (photosynthetically active radiation, PAR) and quality (red : far-red ratio, R:Fr) in riparian reaches heavily invaded by a nonnative tree (Acer platanoides) to that in an uninvaded forest and experimentally tested the effects of our measured differences in PAR and R:Fr on the survival, growth, and biomass allocation of seedlings of the dominant native species and Acer platanoides. Light conditions representative of the understory of Acer platanoides-invaded forest decreased survival of the native maple Acer glabrum by 28\%; Amelanchier alnifolia by 32\%; Betula occidentalis by 55\%; Elymus glaucus by 46\%; and Sorbus aucuparia by 52\%, relative to seedlings growing in PAR similar to that of native understories. In contrast, Acer platanoides and the native shrub Symphoricarpos albus were not affected by reductions in PAR.

Acer platanoides seedlings and saplings are uniquely adapted to shade relative to native species. Acer platanoides was the only species tested that decreased allocation to roots relative to shoots in the invaded forest vs. the native forest light conditions. Therefore it was the only species to demonstrate an adaptive response to the particular light environment associated with Acer platanoides invasion as predicted by optimal partitioning theory.

The profound change in light quantity associated with Acer platanoides canopies appears to act as an important driver of native suppression and conspecific success in invaded riparian communities. Further research is necessary to determine whether the effect of nonnative plantdriven changes on light quantity and quality is a widespread mechanism negatively affecting resident species and facilitating invasion by nonnatives.
\end{abstract} impact.

Key words: Acer platanoides; biological invasion; impact mechanism; quantitative effects; shading

\section{INTRODUCTION}

Despite the wealth of general conceptual hypotheses for why some invaders have such striking effects on native communities, we know little about the basic mechanisms for how "strong invaders" suppress natives (Levine et al. 2003). Our limited understanding of these impact mechanisms affects our ability to predict the potential invasiveness of nonnative species (Rejmanek and Reichard 2001), their effects, or the vulnerability of individual systems to invasions (Elton 1958, Levine and D'Antonio 1999).

Invasive plant species with major effects on community composition and ecosystem-level processes often

Manuscript received 22 December 2005; revised 17 March 2006; accepted 21 March 2006. Corresponding Editor: J. A. Antos.

${ }^{3}$ Present address: Indiana University, Department of Biology, Jordan Hall 127, 1001 East Third Street, Bloomington, Indiana 47405-3700 USA.

E-mail: kureinha@indiana.edu

${ }^{4}$ Present address: University of California, Berkeley, Department of Integrative Biology, Berkeley, California 94720 USA. appear to have traits that are qualitatively different from those of resident species, including novel mutualisms (Vitousek et al. 1987), means of acquiring resources (Chapin et al. 1994), allelopathic compounds (Callaway and Ridenour 2004), or establishing novel disturbance regimes (D'Antonio and Vitousek 1992) . Furthermore, invasiveness has been linked to novelty in other studies (Ricciardi and Atkinson 2004). However, invaders may also succeed by quantitatively amplifying traits that natives possess (Levine et al. 2003).

Norway maple (Acer platanoides Linn.) has invaded northeastern forests of the United States (Wyckoff and Webb 1996, Martin 1999, Webster et al. 2005) and riparian and mesic montane forests of the northern Rocky Mountains (Reinhart et al. 2005, 2006). Reinhart et al. (2005) demonstrated that a riparian reach invaded by Acer platanoides (76\% A. platanoides canopy coverage) had much lower understory species richness $(69 \%$ fewer species) than reaches with low levels of $A$. platanoides invasion $(0-11 \%$ A. platanoides canopy coverage). Plant diversity beneath solitary A. platanoides trees also declined as the size of the trees increased, 
TABLE 1. Nonnative and invasive plants either suspected or known to alter light availability relative to resident species.

\begin{tabular}{ll}
\hline \hline \multicolumn{1}{c}{ Genus } & \multicolumn{1}{c}{ Reference(s) } \\
\hline $\begin{array}{l}\text { Suspected } \\
\text { Acacia }\end{array}$ & Holmes and Cowling (1997) \\
Acer & Wyckoff and Webb (1996), \\
& Bertin et al. (2005), Reinhart \\
& and VandeVoort (2006) \\
Carpinus & Kwiatkowska et al. (1997) \\
Clematis & Ogle et al. (2000) \\
Various grass species & D'Antonio et al. (1998) \\
Lespedeza & Brandon et al. (2004) \\
Ligustrum & Lavergne et al. (1999) \\
Lonicera & Gould and Gorchov (2000), \\
& Gorchov and Trisel (2003) \\
Myrica & Walker and Vitousek (1991) \\
Pueraria & Forseth and Innis (2004) \\
Rhamnus & Fagan and Peart (2004) \\
Sapium & Siemann and Rogers (2003a) \\
Sargassum & Staehr et al. (2000) \\
Various tropical vines & Horvitz and Koop (2001) \\
Known & \\
Acer & Reinhart et al. (2006) \\
Falcataria & Hughes and Denslow (2005) \\
Melinis & Lenz and Facelli (2003) \\
Mimosa & Braithwaite et al. (1989) \\
Trus & Leege and Murphy (2001) \\
& Standish et al. (2001) \\
\hline &
\end{tabular}

whereas the abundance of conspecifics increased with increasing age of $A$. platanoides trees. Furthermore, reciprocal transplants demonstrated that the growth of A. platanoides seedlings is improved by overstory conspecifics, but seedlings of the two dominant, native canopy tree species are highly suppressed by the invader. Although the mechanism(s) for these changes is unknown, a striking difference that we have observed in riparian forests invaded by $A$. platanoides is the deep shade cast by its canopy (see Plate 1 and images in the Supplement).

Shading affects community composition in natural forests (Pagès et al. 2003), and anecdotal observations often attribute reductions in native species abundance/ diversity in a range of plant communities to shading by nonnative species (Table 1). Here we provide the first experiment testing the effect of simulated light environments representing conditions in understories of a native forest and a forest heavily invaded by $A$. platanoides on seedlings of abundant native and nonnative species while controlling for other differences between invaded and uninvaded sites (e.g., nutrient availability, allelopathy, etc.). We tested the effect of light quantity and quality associated with invaded and uninvaded riparian forests on the survival, growth, and resource allocation of seedlings of resident species and $A$. platanoides.

\section{Methods And Materials}

\section{Study area}

We described the canopy structure and understory light of neighboring riparian reaches of mixed deciduous forest along a 3.4-km section of the lower drainage of the Rattlesnake Creek, Montana, USA. Since riparian vegetation can vary naturally because of many factors (geological substrate, hydrology, disturbance history, etc.; Foote 1965), we sampled along a short (3.4 km) and topographically homogeneous section of the creek in order to minimize potentially confounding site effects. Research was conducted in two reaches that differed substantially in the abundance of Acer platanoides (see Supplement). One reach was heavily invaded by $A$. platanoides $(76 \%$ A. platanoides canopy coverage; $\left.46^{\circ} 52.644^{\prime} \mathrm{N}, 113^{\circ} 58.565^{\prime} \mathrm{W}\right)$, and one had low levels of invasion $\left(0 \%\right.$; $\left.46^{\circ} 53.969^{\prime} \mathrm{N}, 113^{\circ} 58.345^{\prime} \mathrm{W}\right)$ (Reinhart et al. 2005). We refer to the reach with low levels of $A$. platanoides invasion $(0 \%)$ as being "native."

Black cottonwood (Populus trichocarpa T. \& G.), ponderosa pine (Pinus ponderosa Dougl.), and Rocky Mountain maple (Acer glabrum Torr.) trees dominated the original native riparian community in our study area (Foote 1965). Acer platanoides is a large tree relative to the native congener Acer glabrum, which is a small tree to shrub, often with clumped stems. Riparian reaches with currently low levels of Acer platanoides invasion have understories dominated by grasses, forbs, and shrubs (Foote 1965, Reinhart et al. 2005). The 15 species with greatest cover in the understory of these reaches are (starting with the most abundant): Symphoricarpos albus, Acer platanoides, Cynoglossum officinale, Populus trichocarpa, Osmorhiza chilensis, Elymus glaucus, Amelanchier alnifolia, Sorbus aucuparia, Galium triflorum, Acer glabrum, Rosa nutkana, Prunus virginiana, Solanum dulcamara, Arctium lappa, and Equisetum hyemale (Reinhart et al. 2005). Refer to Reinhart et al. (2005) for a more detailed description of the climate, soils, community composition of the reaches, etc.; and refer to Foote (1965) for a detailed description of the community composition prior to invasion by Acer platanoides.

\section{Effect of Acer platanoides on canopy structure and understory light}

We collected comparative data describing the canopy cover and understory light environments along a heavily invaded reach and native reach. We also compared the understory light environments between an invaded area (near Populus trichocarpa and Acer platanoides) and where $A$. platanoides had been selectively removed (near $P$. trichocarpa trees). For further details on this portion of the methodology refer to the Appendix.

\section{Effect of light quantity and quality on seedlings}

Because community composition in the understory of Acer platanoides is strikingly different than in native riparian forests (Reinhart et al. 2005), we compared in a greenhouse experiment the effect of light quantity and quality that we measured in the heavily invaded and native riparian reaches (Fig. 1, Table 2) on the survival, growth, and biomass allocation of native and nonnative species that occur in our study system. Six of the seven 


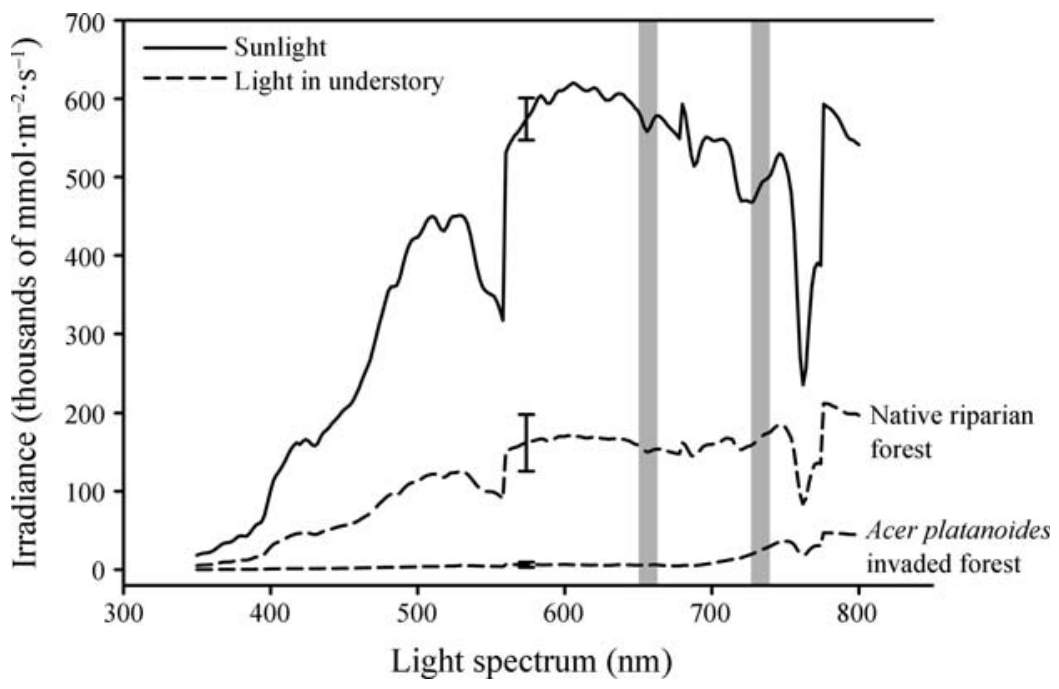

FIG. 1. Light spectra in open patches, understories of native riparian forests, and understories of riparian forests invaded by Acer platanoides. Bars represent the maximum 95\% cI for each curve. Vertical shaded bars represent the red (656-664 nm) and farred $(726-734 \mathrm{~nm})$ portions of the spectrum. The visible portion of the spectrum is from 380 to $750 \mathrm{~nm}$. Discussion of the methods is provided in the Appendix.

species used were among the 15 most abundant species in the understory of our study system and include: a native grass (Elymus glaucus Buckl.), native shrubs (Amelanchier alnifolia Nutt. and Symphoricarpos albus (L.) Blake), native trees (Acer glabrum and Betula occidentalis Hook.), and nonnative trees (Acer platanoides and Sorbus aucuparia L.).

The light quantity (photosynthetically active radiation, PAR) and light quality (ratio of red [656-664 $\mathrm{nm}$ of the electromagnetic spectrum] to far-red light [726-734 nm], $\mathrm{R}: \mathrm{Fr}$ ) associated with a heavily invaded (low PAR and low $\mathrm{R}: \mathrm{Fr}$ ) riparian reach and a native riparian reach (high PAR and high R:Fr) were determined (see Table 2 and the Appendix for a description of the methods). A $2 \times 2$ factorial design was used to simulate native and invaded conditions and test the effect of light quantity (low PAR, invaded condition; high PAR, native condition) and light quality (low R:Fr, invaded condition; high R:Fr, native condition) on seedling survival, growth, and allocation. To simulate the light quality that we measured in native and invaded forest understories (Table 2), we used green filters (Lee Filters, Burbank, California, USA). We used a Lee filter 88 to simulate R:Fr in the understory of a riparian forest invaded by Acer platanoides $(\mathrm{R}: \mathrm{Fr}=0.31$ determined with spectroradiometer) and a Lee filter 122 to simulate light quality in the understory of a native riparian forest $(\mathrm{R}: \mathrm{Fr}=0.72)$.

Neutral light filters (Lee Filters) were used to reduce PAR to levels measured in the understories of native and invaded reaches (Table 2). Ideally, PAR would have remained exactly the same between $\mathrm{R}: \mathrm{Fr}$ treatments; however, slight differences in the effects of the different R:Fr filters on PAR made this impossible. We made PAR differences between R:Fr treatments very closely comparable by combining neutral filters to produce
PAR levels for the invaded R:Fr treatments that were slightly higher (445 and $\left.18 \mu \mathrm{mol} \cdot \mathrm{m}^{-2} \cdot \mathrm{s}^{-1}\right)$ and lower (412 and $\left.10 \mu \mathrm{mol} \cdot \mathrm{m}^{-2} \cdot \mathrm{s}^{-1}\right)$ than the levels of the native $\mathrm{R}: \mathrm{Fr}$ treatments $\left(\mathrm{PAR}=430\right.$ and $14 \mu \mathrm{mol} \cdot \mathrm{m}^{-2} \cdot \mathrm{s}^{-1}, n=8$ per treatment). Thus the mean PAR levels were comparable for R:Fr treatments within individual PAR treatments (i.e., 428.5 vs. 430 for the native PAR treatments and 14 vs. 14 for the invaded PAR treatments). Data for native $\mathrm{R}:$ Fr treatments were pooled in the invaded $(n=16)$ and native PAR treatments $(n=16)$.

Green and neutral filters were attached to the open top of a cardboard frame $(61.00 \times 45.75 \mathrm{~cm}$ [side facing north/south $\times$ side facing east/west]). The side to the south was $10 \mathrm{~cm}$ tall and the east/west sides sloped up from the south side at a $15^{\circ}$ angle to maximize irradiance in the naturally lit greenhouse. We measured the PAR and temperature under each box to validate the treat-

TABLE 2. Canopy cover (leaf area index, LAI) and understory light quantity (photosynthetically active radiation, PAR, mean $\pm 95 \% \mathrm{CI}$ ) and quality (red:far-red, R:Fr) in open patches and in understories of a native riparian reach $(0 \%$ Acer platanoides canopy coverage) and a reach heavily invaded by Acer platanoides (76\% Acer platanoides canopy coverage).

\begin{tabular}{lccc}
\hline \hline Variables & LAI $\left(\mathrm{m}^{2} / \mathrm{m}^{2}\right)$ & $\begin{array}{c}\mathrm{PAR} \\
\left(\mu \mathrm{mol} \cdot \mathrm{m}^{-2} \cdot \mathrm{s}^{-1}\right)\end{array}$ & $\mathrm{R}: \mathrm{Fr}$ \\
\hline Full sun & 0 & $\sim 1800$ & $1.74 \pm 0.20$ \\
Native & $1.88 \pm 0.25$ & $397.5 \pm 93.22$ & $0.64 \pm 0.13$ \\
Invaded & $\mathbf{4 . 2 1} \pm \mathbf{0 . 0 2}$ & $\mathbf{1 7 . 2} \pm \mathbf{7 . 6 7}$ & $\mathbf{0 . 2 7} \pm \mathbf{0 . 1 3}$
\end{tabular}

Notes: The data for the reach heavily invaded by $A$. platanoides appear in boldface type. Refer to the Appendix for a discussion of the methods corresponding with these data and other results substantiating the idea that $A$. platanoides invasion alters riparian forest structure and understory light quantity and quality. 
TABLE 3. ANOVA results for the effect of light quantity (photosynthetically active radiation, PAR), light quality (red:far-red ratio, R:Fr), and interactions on the biomass, height, and root: mass ratio of seedlings of native shrub (Amelanchier alnifolia and Symphoricarpos albus) and tree species (Acer glabrum) and a nonnative tree species (Acer platanoides).

\begin{tabular}{|c|c|c|c|c|c|c|}
\hline \multirow[b]{2}{*}{ Species } & \multicolumn{2}{|c|}{ PAR } & \multicolumn{2}{|c|}{$\mathrm{R}: \mathrm{Fr}$} & \multicolumn{2}{|c|}{ PAR $\times$ R:Fr } \\
\hline & $F$ & $P$ & $F$ & $P$ & $F$ & $P$ \\
\hline \multicolumn{7}{|c|}{ Acer platanoides $(\mathrm{df}=1,42)$} \\
\hline Biomass $(\log [x])$ & 54.07 & $<0.0005$ & 0.27 & 0.61 & 0.84 & 0.37 \\
\hline Height & 9.39 & 0.004 & 0.35 & 0.56 & 2.11 & 0.15 \\
\hline Root: mass ratio & 11.68 & 0.001 & 5.46 & 0.02 & 10.18 & 0.003 \\
\hline \multicolumn{7}{|c|}{ Acer glabrum $(\mathrm{df}=1,39)$} \\
\hline Biomass $\left(\sin ^{-1} \sqrt{[x]}\right)$ & 29.93 & $<0.0005$ & 4.87 & 0.03 & 4.50 & 0.04 \\
\hline Height & 7.07 & 0.01 & 3.34 & 0.08 & 3.58 & 0.06 \\
\hline Root: mass ratio & 13.92 & 0.001 & 3.98 & 0.05 & 0.01 & 0.93 \\
\hline \multicolumn{7}{|c|}{ Amelanchier alnifolia $(\mathrm{df}=1,29)$} \\
\hline Biomass $\left(\sin ^{-1} \sqrt{ }[x]\right)$ & 18.82 & $<0.0005$ & 1.02 & 0.32 & 1.05 & 0.32 \\
\hline Height & 8.03 & 0.01 & 0.01 & 0.94 & 0.004 & 0.95 \\
\hline Root: mass ratio & 5.71 & 0.02 & 2.36 & 0.14 & 1.40 & 0.25 \\
\hline \multicolumn{7}{|c|}{ Symphoricarpos albus $(\mathrm{df}=1,32)$} \\
\hline Biomass $(\log [x])$ & 19.38 & $<0.005$ & 2.00 & 0.17 & 1.74 & 0.20 \\
\hline Height $(\log [x])$ & 41.29 & $<0.0005$ & 0.15 & 0.71 & 0.002 & 0.96 \\
\hline Root: mass ratio & 0.03 & 0.87 & 3.14 & 0.09 & 0.56 & 0.46 \\
\hline
\end{tabular}

Note: Species followed by relevant transformation.

ments and identify any differences in temperature associated with the treatments. Tukey hsd post hoc analyses revealed no significant differences in temperature between treatments (data not shown).

All individuals of a species were collected as recently germinated seedlings from either the heavily invaded reach or a neighboring reach with intermediate levels of invasion $\left(46^{\circ} 53.416^{\prime} \mathrm{N}, 113^{\circ} 58.254^{\prime} \mathrm{W}\right)$ in the spring of 2002. For a species, we collected individuals that were similar in size and then randomly assigned individuals to light treatments. Rocket pots $\left(525 \mathrm{~cm}^{3}\right)$ were filled with a $1: 1$ ratio of silica sand averaging $0.60-0.85 \mathrm{~mm}$ in diameter (20/30 grit; Lane Mountain, Valley City, Washington, USA) and potting soil (Hyponex; Scotts, Marysville, Ohio, USA). One seedling was planted in each pot, and pots were randomly arranged on racks in a naturally lit greenhouse (Dietert Gardens, University of Montana). After a two-week acclimation period, seedlings were randomly assigned to experimental light treatments ( $n=8$ for native R:Fr or 16 for invaded R:Fr treatments). Seedlings were watered once every 1-2 days and fertilized once at the beginning of the experiment with $4.5 \mathrm{~mL} /$ pot of Osmocote slow-release fertilizer (196-12 N-P-K, Scotts). Seedlings were grown for 85 days in the experimental light treatments and harvested on 25 September 2002. Seedling survival, biomass (i.e., root, shoot, and total biomass), and stem height were recorded. Survival data were compared for each species separately with a log-linear analysis designed to test the individual effect and interaction of PAR and R:Fr treatments using SAS version 8.0 (SAS Institute, Cary, North Carolina, USA). To maintain homogeneity of variances for these analyses, we transformed the biomass data (Acer glabrum, Acer platanoides, Ame- lanchier alnifolia, and Symphoricarpos albus) and height data (Symphoricarpos albus) with either $\log _{10}[x]$ or $\sin ^{-1} \sqrt{[x]}$ (see Table 3 ). Even after transformation, the biomass data continued to violate the homogeneity of variances assumption. Analysis of variance was still used, because it is robust to heterogeneity of variances (Underwood 2002). Species with no mortality in a treatment created "sampling zeros," and the data for these species were transformed by adding a small constant $(X+0.01)$ (Agresti 2002). The biomass, height, and root: mass ratio (root mass $\div$ total biomass) data were analyzed for species that maintained relatively high survival across treatments (i.e., Acer glabrum, Acer platanoides, Amelanchier alnifolia, and Symphoricarpos albus) using a two-way ANOVA with PAR and R:Fr as fixed effects. We also tested for an effect of native (high PAR and high R:Fr) and nonnative conditions (low PAR and low R:Fr) on seedling survival with log-linear tests and on growth/allocation with $t$ tests.

\section{RESUlts}

\section{Effect of Acer platanoides on canopy structure and understory light}

At the scale of entire reaches, native canopies dominated by Populus trichocarpa reduced total PAR to $\sim 400 \mu \mathrm{mol} \cdot \mathrm{m}^{-2} \cdot \mathrm{s}^{-1}$, or $20 \%$ of full sunlight (Fig. 1, Table 2). However, the riparian reach heavily invaded by $A$. platanoides had dramatically higher canopy cover and much lower light levels in the understory (Fig. 1). This reach had a mean PAR of $17 \mu \mathrm{mol} \cdot \mathrm{m}^{-2} \cdot \mathrm{s}^{-1},<5 \%$ that in the native riparian reach (Table 2). Leaf area index was $123 \%$ greater in the reach now dominated by A. platanoides than in a native riparian reach (Table 2). 


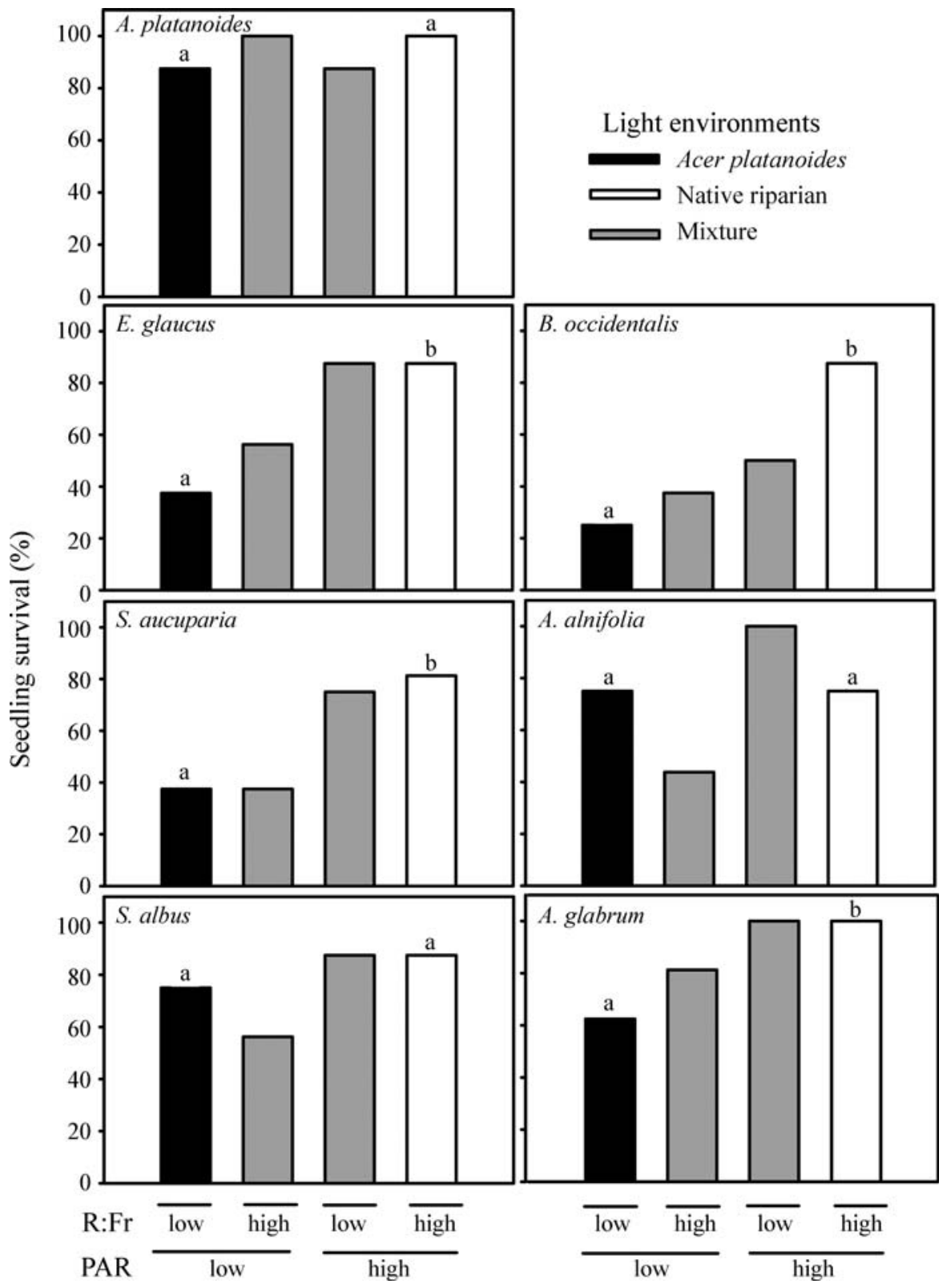

FIG. 2. Effect of light quantity (photosynthetically active radiation, PAR) and quality (red : far-red ratio, R:Fr) on seedling survival. Seedling species include: Acer glabrum, Acer platanoides, Amelanchier alnifolia, Betula occidentalis, Elymus glaucus, Sorbus aucuparia, and Symphoricarpos albus ( $n=8$ seedlings for the low R:Fr treatment and 16 seedlings for the high R:Fr treatment). Different lowercase letters indicate a significant difference among the means $(P \leq 0.05)$ in the native (high PAR and high R:Fr) and nonnative conditions (low PAR and low R:Fr) according to log-linear tests. Two-way log-linear results are reported in Results.

Not only did the heavily invaded reach have greater canopy cover and reduced energy flow (total PAR) to the understory, the R:Fr ratios were $58 \%$ lower than in the native riparian reach (Table 2). At the scale of individual trees, PAR under $A$. platanoides canopies $(40.02 \pm 15.53$ $\mu \mathrm{mol} \cdot \mathrm{m}^{-2} \cdot \mathrm{s}^{-1}$, mean $\pm \mathrm{SE}$ ) was $25 \%$ of that under Populus trichocarpa trees in areas where A. platanoides had been selectively removed $\left(163 \pm 67.74 \mu \mathrm{mol} \cdot \mathrm{m}^{-2} \cdot \mathrm{s}^{-1}\right.$; $t$ test, $t=-3.92, \mathrm{df}=34, P<0.0005)$.

\section{Effect of light quantity and quality on seedlings}

Across both R:Fr treatments, low PAR, comparable to that in invaded understories, decreased survival of the native maple Acer glabrum by 28\%; Amelanchier alnifolia by $32 \%$; Betula occidentalis by $55 \%$; Elymus glaucus by $46 \%$; and Sorbus aucuparia by $52 \%$ relative to seedlings growing in PAR similar to that of native understories (Fig. 2, log-linear analysis, Acer glabrum, $\chi^{2}$ 


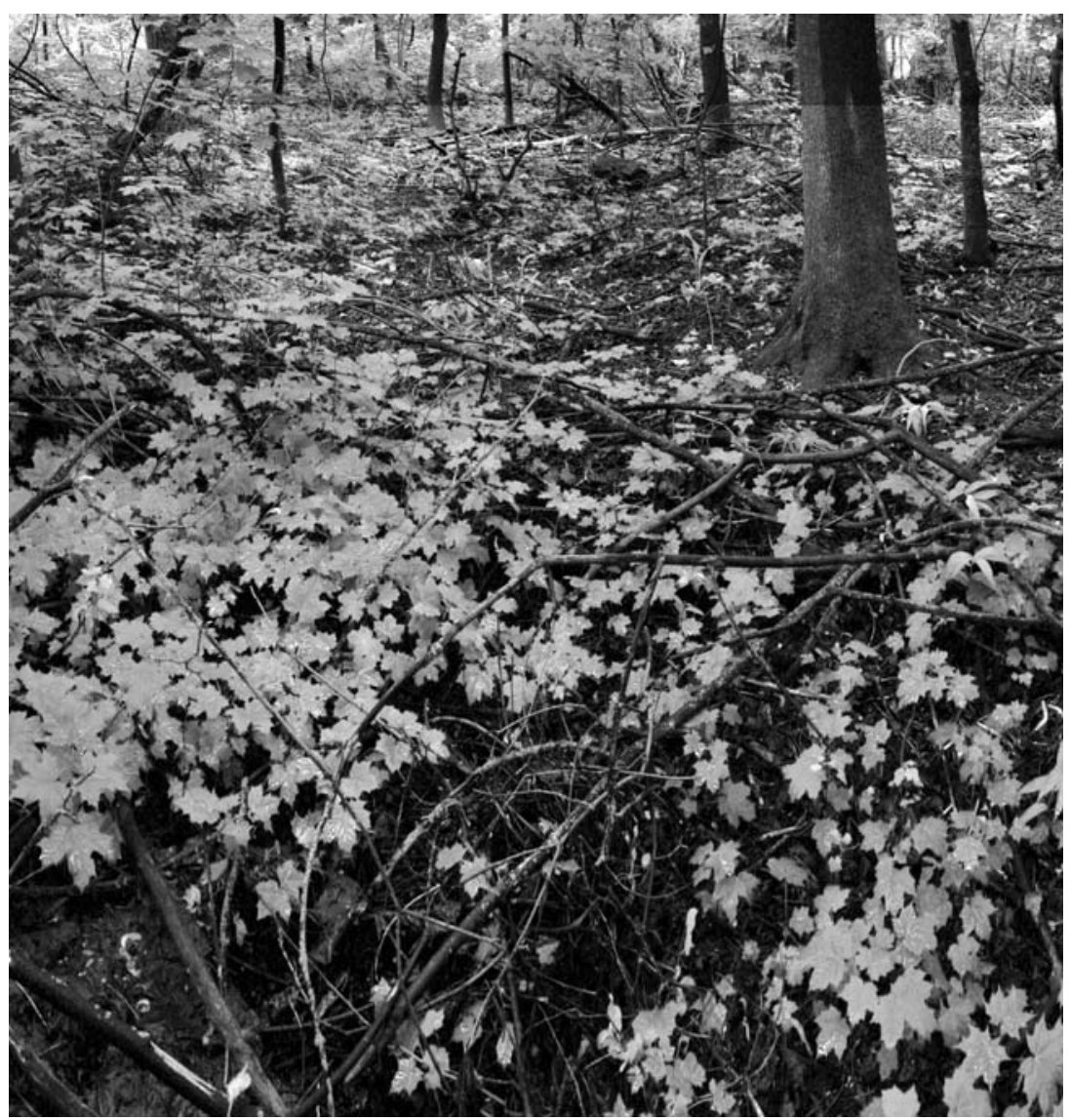

Plate 1. Understory dominated by seedlings of Acer platanoides in a forest heavily invaded by this species. Photo credit: K. Reinhart.

6.84, $P=0.009 ;$ Amelanchier alnifolia, $\chi^{2}=6.88, P=$ 0.009 ; Betula occidentalis, $\chi^{2}=6.31, P=0.01 ;$ Elymus glaucus, $\chi^{2}=6.89, P=0.009 ;$ Sorbus aucuparia, $\chi^{2}=$ $6.85, P=0.0088$; all $\mathrm{df}=1)$. In contrast, Acer platanoides and the native shrub Symphoricarpos albus were not affected by reductions in PAR (decreased survival by $0 \%$ and $25 \%$, respectively; Fig. 2, Acer platanoides, $\chi^{2}=0, P$ $=1.00$ and Symphoricarpos albus, $\chi^{2}=2.45, P=0.12$; all df $=1)$.

The low PAR and low R:Fr levels associated with invaded forests relative to native riparian forest reduced the survival of most tested native and nonnative species common at our field sites, but it had no effect on Acer platanoides seedlings. When both light quantity and quality of invaded forests were mimicked (low PAR and low R:Fr) mortality of native species was much higher in invaded environments than native environments (high PAR and high R:Fr). Acer glabrum survival decreased by $38 \%$, Betula occidentalis by $57 \%$, Elymus glaucus by $57 \%$, and Sorbus aucuparia seedlings by 53\% (Fig. 2). Overall, Acer platanoides maintained the highest survival in invaded light conditions (87.5\%, Fig. 2).

By itself, R:Fr had no effect on the seedling survival of most species (Acer glabrum, $\chi^{2}=0.07, P=0.79$; Acer platanoides, $\chi^{2}=0.59, P=0.44 ;$ Amelanchier alnifolia, $\chi^{2}$
$=0.24, P=0.63 ;$ Elymus glaucus, $\chi^{2}=0.23, P=0.63$; Sorbus aucuparia, $\chi^{2}=0.07, P=0.79 ;$ Symphoricarpos albus, $\chi^{2}=0.27, P=0.60$; all $\mathrm{df}=1$ ). However, there was a marginally significant effect of R:Fr toward increasing the mortality of native Betula occidentalis seedlings $\left(\chi^{2}=\right.$ $3.20, P=0.074)$. There was no interaction in the effect of PAR and R:Fr on seedling survival (Acer glabrum, $\chi^{2}=$ $0.07, P=0.79$; Acer platanoides, $\chi^{2}=0.00, P=1.00$; Amelanchier alnifolia, $\chi^{2}=0.23, P=0.63$; Elymus glaucus, $\chi^{2}=0.23, P=0.63$; Sorbus aucuparia, $\chi^{2}=0.07$, $P=0.79 ;$ Symphoricarpos albus, $\chi^{2}=0.27, P=0.60$; all $\mathrm{df}$ $=1)$.

For the four species with the highest overall survival (Acer glabrum, Acer platanoides, Amelanchier alnifolia, and Symphoricarpos albus), reduction in light quantity mimicking Acer platanoides invasion reduced the height and biomass of all four tested species relative to seedlings grown in light quantities similar to those in native riparian areas (Fig. 3, Table 3). In contrast, R:Fr alone affected only Acer glabrum. There was no effect of $\mathrm{R}:$ Fr or PAR $\times \mathrm{R}:$ Fr on the biomass of Acer platanoides, Amelanchier alnifolia, and Symphoricarpos albus or the height of the four tested species (Table 3). The biomass of Acer glabrum seedlings was $21 \%$ less in low R:Fr (conditions created by Acer platanoides) than high $\mathrm{R}: \mathrm{Fr}$ 

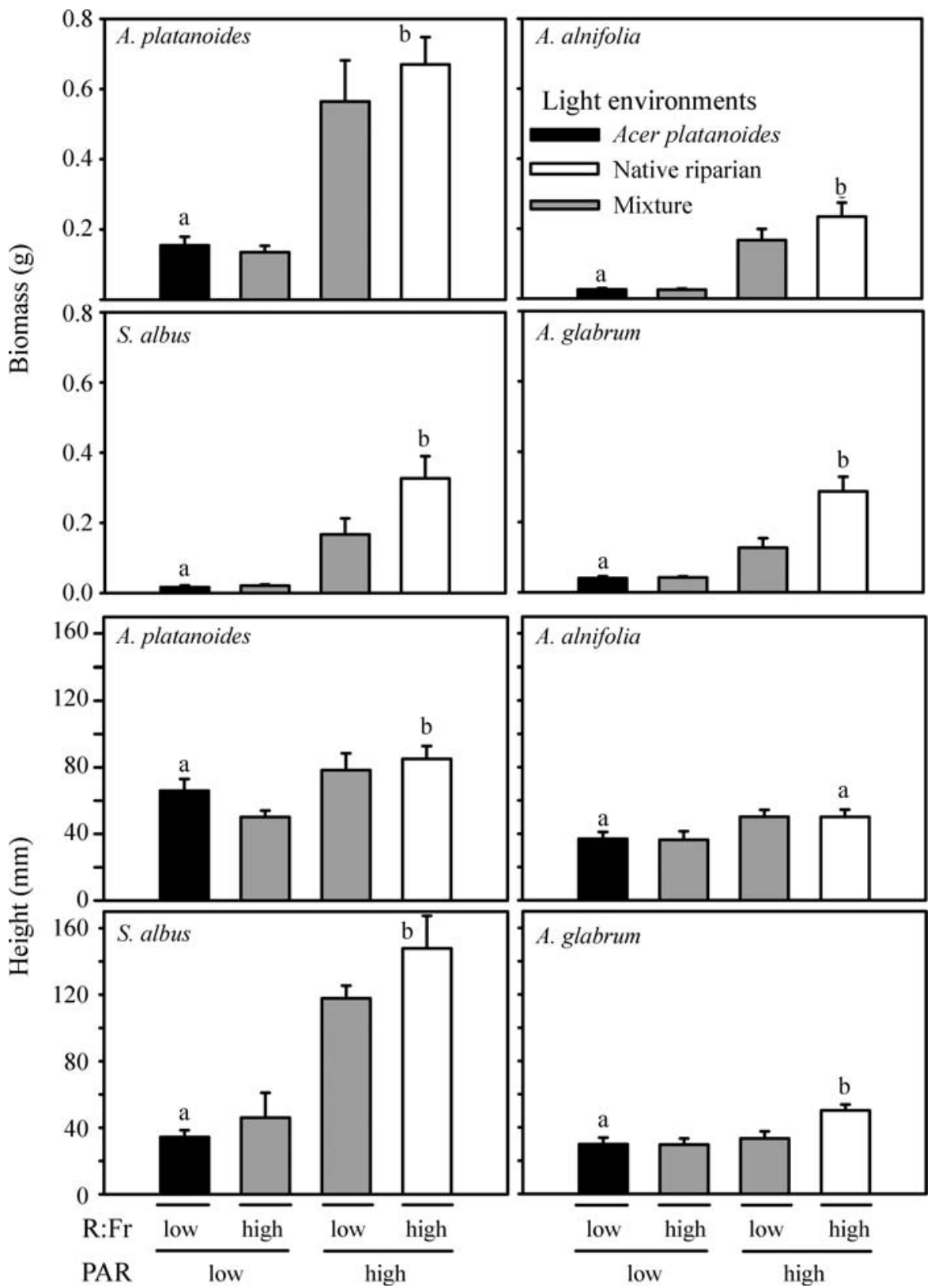

FIG. 3. Effect of light quantity (photosynthetically active radiation, PAR) and quality (red : far-red ratio, R:Fr) on the total biomass and height of Acer glabrum, Acer platanoides, Amelanchier alnifolia, and Symphoricarpos albus seedlings $(n=5-8$ seedlings for the low R:Fr treatment and 9-16 seedlings for the high R:Fr treatment). Error bars represent +SE, and different lowercase letters indicate a significant difference among the means $(P \leq 0.05)$ in the native (high PAR and high $\mathrm{R}: \mathrm{Fr}$ ) and nonnative conditions (low PAR and low R:Fr) according to $t$ tests. Two-way ANOVA results are reported in Results.

treatments (Table 3). Acer glabrum biomass was also $\geq 34 \%$ greater in the treatment with high PAR and high $\mathrm{R}: \mathrm{Fr}$ (light conditions under native canopies) relative to other treatments (Table 3). The height and biomass of all tested species were smaller when grown in the invaded (low PAR and low R:Fr) vs. native light environments (high PAR and high R:Fr) except for the height of Amelanchier alnifolia, which did not differ between simulated environments (Fig. 3).
Reductions in PAR elicited similar changes in the biomass allocation of native and Acer platanoides seedlings. However, the effect of R:Fr and the interactive effect of PAR and R:Fr on allocation were more complicated and often differed in unique ways between the invader and native species. Simulated Acer platanoides-driven reductions in PAR decreased the root:mass ratios of $A$. platanoides and two of three native species (A. platanoides by $22 \%$, Acer glabrum by $28 \%$ and Amelanchier alnifolia 


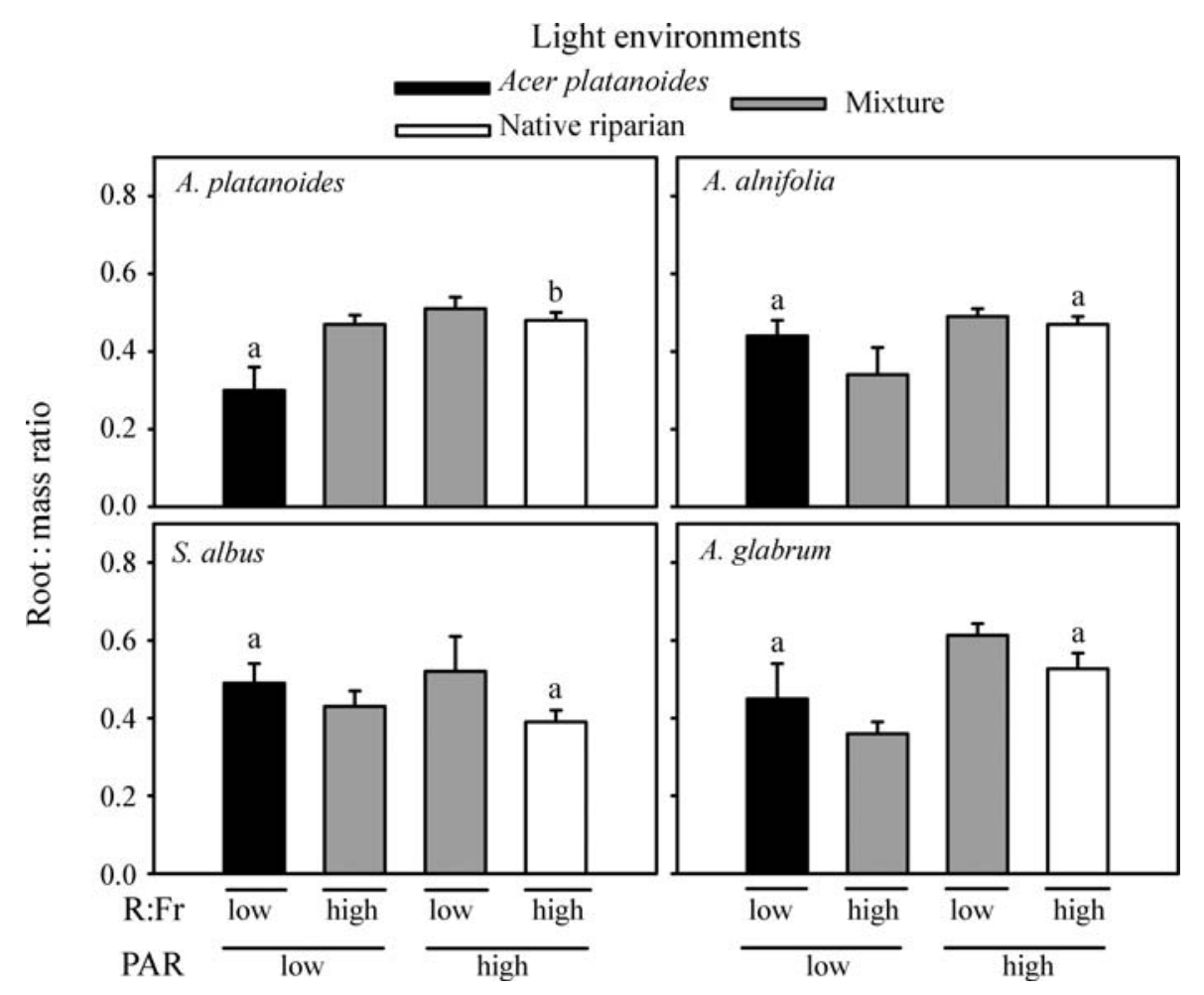

FIG. 4. Effect of light quantity (photosynthetically active radiation, PAR) and quality (red:far-red ratio, R:Fr) on the root : mass ratio (root mass divided by total biomass) of Acer glabrum, Acer platanoides, Amelanchier alnifolia, and Symphoricarpos albus seedlings. Error bars represent + SE, and different lowercase letters indicate a significant difference among the means $(P \leq$ 0.05 ) in the native (high PAR and high R:Fr) and nonnative conditions (low PAR and low R:Fr) according to $t$ tests. Two-way ANOVA results are reported in Results.

seedlings by $19 \%$ ) relative to seedlings in PAR levels similar to those found in native riparian forests (Fig. 4, Table 3). Thus, reductions in PAR triggered three of four species to allocate proportionally more resources to shoots than roots. The root: mass ratios of two native species were unresponsive to changes in R:Fr; however, experimental reductions in R:Fr increased the root: mass ratio of Acer glabrum seedlings by $18 \%$ (Table 3). In contrast, reductions in R:Fr decreased the root:mass ratio of Acer platanoides by $14 \%$ relative to seedlings in high R:Fr (Table 3).

There was an interactive effect of PAR and R:Fr on the biomass allocation of Acer platanoides (root:mass ratio) but not on native species (Fig. 4, Table 3). Furthermore, native species had similar root:mass ratios when grown in native (high PAR and high $\mathrm{R}: \mathrm{Fr}$ ) vs. invaded light environments (low PAR and low R:Fr; Fig. 4). In contrast, the invaded light environment caused a $38 \%$ reduction in the root:mass ratios of $A$. platanoides seedlings relative to plants grown in conditions similar to those in native riparian areas. Overall, A. platanoides was the only species tested to proportionally increase allocation to shoots in response to the combined reductions in PAR and R:Fr characteristic of $A$. platanoides-invaded forests.

\section{Discussion}

Many nonnative species decrease the richness and alter the composition of the communities they invade (Selleck et al. 1962, Ridenour and Callaway 2001, Siemann and Rogers 2003b, Reinhart et al. 2005; refer to Levine et al. [2003] for 33 additional citations). In a review, Levine et al. (2003) reported that only $5 \%$ of studies explored the mechanisms causing these impacts. We observed profound changes in light quantity and quality associated with Acer platanoides invasion $(<5 \%$ PAR in a native riparian area; Fig. 1, Table 2, and Supplement) and found that the reductions in light quantity appear to drive native suppression and $A$. platanoides success in invaded riparian communities in western Montana, USA. Our results indicate that $A$. platanoides simply creates a degree of shade atypical of the uninvaded riparian forests and support the idea that quantitative changes elicited by invasive species can lead to overwhelming dominance by the invader and strong inhibition of natives. Shade is not qualitatively novel. Shade affects most if not all ecological systems. However, the quantitative effects of $A$. platanoides, in a system relatively depauperate of shade-tolerant native woody species (Hansen et al. 1995), creates conditions that suppress other species and that favor its own offspring (Reinhart et al. 2005). Historically, distur- 
bance in the form of flooding and fire played an important role in affecting the structure and composition of this riparian system. The recent alteration of these natural disturbance regimes (e.g., stream flow at study sites regulated by a dam established in 1905) has probably played an important role in facilitating the invasion of $A$. platanoides and the development of a system structurally and functionally similar to a latesuccessional deciduous forest. Reinstating either of these disturbance regimes may help favor native vs. nonnative species.

Changes in light quantity (PAR) regulate shade tolerance adaptations (Smith 1982, Lambers et al. 2000), while changes in R:Fr are thought to induce shade avoidance phenotypes (e.g., Morgan and Smith 1979, Gilbert et al. 2001). Although simulated $A$. platanoides-driven reductions in PAR had a negative effect on the growth of all species including $A$. platanoides, A. platanoides responded to changes in PAR and R:Fr by allocating resources in a novel and adaptive way relative to resident species. For example, low root: shoot ratios are a common developmental response to shading (e.g., Chapin 1980, Givnish 1988, Lei and Lechowicz 1998). As predicted by optimal partitioning theory (Chapin 1980), low PAR, mimicking that under $A$. platanoides, resulted in lower root: mass ratios for three of four species including A. platanoides. However, increases in overstory canopy cover in nature are generally associated with reductions in PAR and R:Fr (e.g., Frankland and Poo 1980). In our study, examining PAR alone provides an inflated estimate of the adaptive responses of native species to invasive light conditions. When comparing species responses to light quantity and quality together, A. platanoides was the only species tested that decreased allocation to roots relative to shoots in invaded conditions and therefore was the only species to demonstrate an adaptive response to the combined qualitative and quantitative light conditions associated with $A$. platanoides invasion. Thus, the relatively high survival of $A$. platanoides in invaded light environments (low PAR, low R:Fr) relative to native species appears to result from the invader's tolerance to deep shade produced by itself (i.e., low PAR and R:Fr). The shade tolerance of $A$. platanoides seedlings and saplings results in part from their ability to shift biomass allocation in varying light environments in a way that is consistent with optimal partitioning theory, deviates from natives, and includes altering root: mass ratios and increasing leaf area with stem height more rapidly than natives do in deep shade (see Appendix).

Reproductive strategies may play an important role in forest succession (Forcier 1975). Our study focused on the affect of altered light regimes on the early stages of seedling development. Resident species that can reproduce clonally (e.g., Symphoricarpos albus) may be more capable of persisting in deep shade. This may help explain why Symphoricarpos albus is the second most abundant native species in the understory at the reach heavily invaded by $A$. platanoides (Reinhart et al. 2005). However, seedlings of this species appear relatively tolerant to shade (Fig. 2). Additional comparative experiments at the later stage of plant growth are necessary to determine whether resident native species continue to decline at low levels of light quantity.

We describe an effect of an invader on a resource that corresponds in part with Tilman's (1982) $\mathrm{R}^{*}$ theory for resource competition. If all species are limited by the same resource, then one species may displace its competitors if it has an $\mathrm{R}^{*}$ (resource level associated with that species grown in monoculture) that is lower than that of the other species. In riparian forests, trees of A. platanoides appear to draw resources in the understory down to a level that only its own seedlings can tolerate, essentially a positive feedback, which maintains "oskars" (a plant in a suppressed juvenile state in the understory of a forest; Silvertown 1987) ready to exploit forest gaps (Wyckoff and Webb 1996, Martin 1999, Reinhart et al. 2005).

Acer platanoides success in riparian communities of the northern Rocky Mountains may be enhanced by its effect on the light regime; however, it is unlikely that this same mechanism is the driver of $A$. platanoides invasion of forests in the northeastern United States. In these forests, other native canopy species (e.g., Acer saccharum and Fagus grandifolia) are functionally and structurally similar and decrease light to roughly similar levels as A. platanoides (K. O. Reinhart, personal observation), and many native species are as tolerant to shade as $A$. platanoides (Canham et al. 1994, Lei and Lechowicz 1998). In contrast, some researchers have argued that $A$. platanoides produces greater shade than native tree species in eastern deciduous forests in the United States (Wyckoff and Webb 1996, Bertin et al. 2005). Moreover, removal of $A$. platanoides trees in a northeastern forest was associated with increased recruitment of native species (Webb et al. 2001). Comparative experiments like the one performed here are necessary to determine whether shade production and tolerance explain the invasive success of $A$. platanoides in deciduous forests of the northeastern United States or whether the invasive success of $A$. platanoides depends on different mechanisms in different plant communities.

Other studies have suggested that some invasive nonnative species reduce light to levels that can suppress native species (Table 1) but few studies have tested this experimentally (Gorchov and Trisel 2003). We cannot say how important this mechanism is relative to other mechanisms, but accurate prediction of the impacts of nonnative species is an important goal of invasion biology and depends on understanding the manner in which nonnative species alter ecosystems and suppress natives. 


\section{ACKNOWLEDGMENTS}

This research benefited from the helpful comments by two anonymous reviewers. We thank Bruce Mahall, Anna Sala, Carol Brewer, Tom Mitchell-Olds, John Maron, and John McKay for letting us borrow research equipment and facilities. We also thank Adam Collins, Julie Reinhart, and Giles Thelen for their tireless assistance in the field and laboratory. This research was funded in part by a Project IBS-CORE Undergraduate Research Fellowship awarded to J. Gurnee, provided by a grant from the Howard Hughes Medical Institute to the University of Montana, an FPI fellowship provided by the Spanish Minister of Education and Science awarded to R. Tirado, funding from the USDA to K. O. Reinhart (NRI 200302047) and funding from the National Science Foundation, the USDA, The Aldo Leopold Wilderness Center, and the Civilian Research and Development Foundation to R. M. Callaway.

\section{Literature Cited}

Agresti, A. 2002. Categorical data analysis. Second edition. Wiley, New York, New York, USA.

Bertin, R. I., M. E. Manner, B. F. Larrow, T. W. Cantwell, and E. M. Berstene. 2005. Norway maple (Acer platanoides) and other non-native trees in urban woodlands of central Massachusetts. Journal of the Torrey Botanical Society 132:225-235.

Braithwaite, R. W., W. M. Lonsdale, and J. A. Estbergs. 1989. Alien vegetation and native biota in tropical Australia: the impact of Mimosa pigra. Biological Conservation 48:189 210.

Brandon, A. L., D. J. Gibson, and B. A. Middleton. 2004 Mechanisms for dominance in an early successional old field by the invasive non-native Lespedeza cuneata (Dum. Cours.) G. Don. Biological Invasions 6:483-493.

Callaway, R. M., and W. M. Ridenour. 2004. Novel weapons: a biochemically based hypothesis for invasive success and the evolution of increased competitive ability. Frontiers in Ecology and the Environment 2:436-443.

Canham, C. D., A. C. Finzi, S. W. Pacala, and D. H. Burbank. 1994. Causes and consequences of resource heterogeneity in forests: interspecific variation in light transmission by canopy trees. Canadian Journal of Forest Research 24:337-349.

Chapin, F. S., III. 1980. The mineral nutrition of wild plants. Annual Review of Ecology and Systematics 11:233-260.

Chapin, F. S., III., H. L. Reynolds, C. M. D'Antonio, and V. M. Eckhart. 1994. The functional role of species in terrestrial ecosystems. Pages 403-428 in B. Walker and W. Steffen, editors. International geosphere-biosphere programme book series. Cambridge University Press, Cambridge, UK.

D'Antonio, C. M., R. F. Hughes, M. Mack, D. Hitchcock, and P. M. Vitousek. 1998. The response of native species to removal of invasive exotic grasses in a seasonally dry Hawaiian woodland. Journal of Vegetation Science 9:699712.

D'Antonio, C. M., and P. M. Vitousek. 1992. Biological invasions by exotic grasses, the grass/fire cycle, and global change. Annual Review of Ecology and Systematics 23:6387.

Elton, C. S. 1958. The ecology of invasions by animals and plants. Methuen, London, UK.

Fagan, M. E., and D. R. Peart. 2004. Impact of the invasive shrub glossy buckthorn (Rhamnus frangula L.) on juvenile recruitment by canopy trees. Forest Ecology and Management 194:95-107.

Foote, G. G. 1965. Phytosociology of the bottomland hardwood forests of western Montana. Thesis. University of Montana, Missoula, Montana, USA.

Forcier, L. K. 1975. Reproductive strategies and the cooccurence of climax tree species. Science 189:808-810.

Forseth, I., and A. Innis. 2004. Kudzu (Pueraria montana): history, physiology, and ecology combine to make a major ecosystem threat. Critical Reviews in Plant Sciences 23:401413.

Frankland, B., and W. K. Poo. 1980. Phytochrome control of seed germination in relation to natural shading. Pages $357-$ 366 in J. de Greef, editor. Photo receptors in plant development. University Press, Antwerpen, The Netherlands.

Gilbert, I. R., P. G. Jarvis, and H. Smith. 2001. Proximity signal and shade avoidance differences between early and late successional trees. Nature 411:792-795.

Givnish, T. J. 1988. Adaptation to sun and shade: a whole-plant perspective. Australian Journal of Plant Physiology 15:63-92.

Gorchov, D. L., and D. E. Trisel. 2003. Competitive effects of the invasive shrub, Lonicera maackii (Rupr.) Herder (Caprifoliaceae), on the growth and survival of native tree seedlings. Plant Ecology 166:13-24.

Gould, A. M. A., and D. L. Gorchov. 2000. Effects of the exotic invasive shrub Lonicera maackii on the survival and fecundity of three species of native annuals. American Midland Naturalist 144:36-50.

Hansen, P. L., R. D. Pfister, K. C. Boggs, B. J. Cook, J. Joy, and D. K. Hinckley. 1995. Classification and management of Montana's riparian and wetland sites. Montana Forest and Conservation Experiment Station, School of Forestry, The University of Montana, Missoula, Montana, USA.

Holmes, P. M., and R. M. Cowling. 1997. The effects of invasion by Acacia saligna on the guild structure and regeneration capabilities of South African fynbos shrublands. Journal of Applied Ecology 34:317-332.

Horvitz, C. C., and A. Koop. 2001. Removal of nonnative vines and post-hurricane recruitment in tropical hardwood forests of Florida. Biotropica 33:268-281.

Hughes, R. F., and J. S. Denslow. 2005. Invasion by a $\mathrm{N}_{2}$-fixing tree alters function and structure in wet lowland forests of Hawaii. Ecological Applications 15:1615-1628.

Kwiatkowska, A. J., K. Spalik, E. Michalak, A. Palinska, and D. Panufnik. 1997. Influence of the size and density of Carpinus betulus on the spatial distribution and rate of deletion of forest-floor species in thermophilous oak forest. Plant Ecology 129:1-10.

Lambers, H., F. S. Chapin, III, and T. L. Pons. 2000. Plant physiological ecology. Springer-Verlag, New York, New York, USA.

Lavergne, C., J. Rameau, and J. Figier. 1999. The invasive woody weed Ligustrum robustum subsp. walkeri threatens native forest on La Réunion. Biological Invasions 1:377-392.

Leege, L. M., and P. G. Murphy. 2001. Ecological effects of the non-native Pinus nigra on sand dune communities. Canadian Journal of Botany 79:429-437.

Lei, T. T., and M. J. Lechowicz. 1998. Diverse responses of maple saplings to forest light regimes. Annals of Botany 82: 9-19.

Lenz, T. I., and J. M. Facelli. 2003. Shade facilitates an invasive stem succulent in a chenopod shrubland in South Australia. Austral Ecology 28:480-490.

Levine, J. M., and C. M. D'Antonio. 1999. Elton revisited: a review of evidence linking diversity and invasibility. Oikos 87:15-26.

Levine, J. M., M. Vilà, C. M. D'Antonio, J. S. Dukes, K. Grigulis, and S. Lavorel. 2003. Mechanisms underlying the impacts of exotic plant invasions. Proceedings of the Royal Society of London 270:775-781.

Martin, P. H. 1999. Norway maple (Acer platanoides) invasion of a natural forest stand: understory consequence and regeneration pattern. Biological Invasions 1:215-222.

Morgan, D. C., and H. Smith. 1979. A systematic relationship between phytochrome-controlled development and species habitat, for plants grown in simulated natural radiation. Planta 145:253-258.

Ogle, C. C., G. D. L. Cock, G. Arnold, and N. Mickleson. 2000. Impact of an exotic vine Clematis vitalba (F. Ranunculaceae) and of control measures on plant biodiver- 
sity in indigenous forest, Taihape, New Zealand. Austral Ecology 25:539-551.

Pagès, J.-P., G. Pache, D. Joud, N. Magnan, and R. Michalet. 2003. Direct and indirect effects of shade on four forest tree seedlings in the French Alps. Ecology 84:2741-2750.

Reinhart, K. O., E. Greene, and R. M. Callaway. 2005. Effects of Acer platanoides invasion on understory plant communities and tree regeneration in the northern Rocky Mountains. Ecography 28:573-582.

Reinhart, K. O., F. T. Maestre, and R. M. Callaway. 2006. Facilitation and inhibition of seedlings of an invasive tree (Acer platanoides) by different tree species in a mountain ecosystem. Biological Invasions 8:231-240.

Reinhart, K. O., and R. VandeVoort. 2006. Effect of native and exotic leaf litter on macroinvertebrate communities and decomposition in a western Montana stream. Diversity and Distributions, in press.

Rejmanek, M., and S. Reichard. 2001. Predicting invaders. Trends in Ecology and Evolution 16:545-546.

Ricciardi, A., and S. K. Atkinson. 2004. Distinctiveness magnifies the impact of biological invaders in aquatic ecosystems. Ecology Letters 7:781-784.

Ridenour, W. M., and R. M. Callaway. 2001. The relative importance of allelopathy in interference: the effects of an invasive weed on a native bunchgrass. Oecologia 126:444450.

Selleck, G. W., R. T. Coupland, and C. Frankton. 1962. Leafy spurge in Saskatchewan. Ecological Monographs 32:1-29.

Siemann, E., and W. E. Rogers. 2003a. Changes in light and nitrogen availability under pioneer trees may indirectly facilitate tree invasions of grasslands. Journal of Ecology 91:923-931.

Siemann, E., and W. E. Rogers. 2003b. Herbivory, disease, recruitment limitation, and success of alien and native tree species. Ecology 84:1489-1505.
Silvertown, J. 1987. Introduction to plant population ecology. John Wiley and Sons, New York, New York, USA.

Smith, H. 1982. Light quality, photoperception and plant strategy. Annual Review of Plant Physiology 33:481-518.

Staehr, P. A., M. F. Pedersen, M. S. Thomsen, T. Wernberg, and D. Krause-Jensen. 2000. Invasion of Sargassum muticum in Limfjorden (Denmark) and its possible impact on the indigenous macroalgal community. Marine Ecology Progress Series 207:79-88.

Standish, R. J., A. W. Robertson, and P. A. Williams. 2001. The impact of an invasive weed Tradescantia fluminensis on native forest regeneration. Journal of Applied Ecology 38: $1253-1263$

Tilman, D. 1982. Resource competition and community structure. First edition. Princeton University Press, Princeton, New Jersey, USA.

Underwood, A. J. 2002. Experiments in ecology. Cambridge University Press, Cambridge, UK.

Vitousek, P. M., L. R. Walker, L. D. Whiteaker, D. MuellerDombois, and P. A. Matson. 1987. Biological invasion by Myrica faya alters ecosystem development in Hawaii. Science 238:802-804.

Walker, L. R., and P. M. Vitousek. 1991. An invader alters germination and growth of a native dominant tree in Hawaii. Ecology 72:1449-1455.

Webb, S. L., T. H., IV Pendergast, and M. E. Dwyer. 2001. Response of native and exotic maple seedling banks to removal of the exotic, invasive Norway maple (Acer platanoides). Journal of the Torrey Botanical Society 128: 141-149.

Webster, C. R., K. Nelson, and S. R. Wangen. 2005. Stand dynamics of an insular population of an invasive tree, Acer platanoides. Forest Ecology and Management 208:85-99.

Wyckoff, P. H., and S. L. Webb. 1996. Understory influence of the invasive Norway maple (Acer platanoides). Bulletin of the Torrey Botanical Club 123:197-205.

\section{APPENDIX}

Further details of methods used for measuring the effect of Acer platanoides on canopy structure and understory light and a table showing allometry of shrubs and saplings naturally occurring in shaded understories (Ecological Archives A016-060-A1).

\section{SUPPLEMENT}

Multirow spherical panoramas in QuickTime Virtual Reality (QTVR) format for depicting native riparian vegetation and riparian vegetation heavily invaded by Acer platanoides occurring adjacent to Rattlesnake Creek, Missoula, Montana, USA, in 2005 (Ecological Archives A016-060-S1). 